\author{
DUŠAN LJ. TODOROVIĆ 1 \\ UNIVERSITY OF NIŠ, FACULTY OF PHILOSOPHY \\ DEPARTMENT OF PSYCHOLOGY \\ DUŠAN J. RANĐELOVIĆ² \\ UNIVERSITY OF PRIŠTINA IN KOSOVSKA MITROVICA \\ FACULTY OF PHILOSOPHY \\ DEPARTMENT OF PSYCHOLOGY \\ DARINKA D. ILIĆ 3 \\ PSYCHOLOGICAL COUNSELLING CENTRE \\ FOR STUDENTS \\ STUDENT CUltural CENTRE, Niš
}

\title{
UNIVERSITY STUDENTS' CENTRE FOR PSYCHOLOGICAL COUNSELLING: EMPIRICAL RESEARCH AND POTENTIAL IMPORTANCE FOR THE IMPROVEMENT OF THE QUALITY OF STUDENT LIFE
}

ABSTRACT. Counselling psychology addresses the emotional, social, work, school, and physical health concerns people may have at different stages in their lives, focusing on typical life stresses and more severe issues with which people may struggle as individuals and as a part of families, groups, and organiza-

\footnotetext{
dusan.todorovic@filfak.ni.ac.rs

dusan.randjelovic@pr.ac.rs

darinka.ilic.98@gmail.com
}

Prepared as part of the project „Fifty years of the Faculty of Philosophy in Niš - retrospectives, practical implications and vision for future generations of psychologists and social workers", conducted at the University of Niš - Faculty of Philosophy (No. 100/1-10-6-01). This study was supported by the MiNištry of Education, Science and Technological Development of the Republic of Serbia (Contract No. 451-03-9/2021-14/200165).

Рад је примљен 15. новембра 2021, а прихваћен за објављивање на састанку Редакције 3борника одржаном 21. децембра 2021. 
tions. The increasing rate of psychological problems and their consequences indicate that student centres that provide psychological assistance have to exist. The pilot project "Psychological counselling centre for students" at the University of Niš is one of the largest and longest running projects of this type among the universities in Serbia. The basic research problem is an attempt to predict the frequency of occurrence of student-related problems regarding: learning and intellectual functioning, emotional relationships, communication, and social relations based on self - concept, quality of family communication and emotional intelligence. The sample consisted of 400 students from University of Niš. A self-concept scale (Bezinović, 1988) was used to measure the self-concepts of adolescents, while (primary) family satisfaction was measured using the Faces IV questionnaire (Olson \& Gorrall, 2006). To estimate emotional intelligence, the Emotional Competence Questionnaire was used (Takšić et al., 2006). Almost all the models were obtained via the hierarchical regression analysis, and proved to be statistically significant, so that the percentage of the explained variance ranges from $7.9 \%$ when it comes to problems in the sphere of emotional relationships, to $24,8 \%$ in the sphere of communication and social relations. This means that the models best functioned precisely when it came to explaining the problem of communication and social functioning among students, even though the percentage of the explained variance of $10,9 \%$ in the case of the problem of studying and intellectual functioning is not negligible. The study of potential and significant factors which could have an impact, whether positive or negative, on the mental health of the student population is and should be an imperative for the scientific and professional community.

KEYWORDS: student centre for psychological counselling; prediction of problems within the student population; student mental health.

\section{THEORETICAL FRAMEWORK}

Counselling psychology is a general practice and health service provider specialty in professional psychology. It focuses on how people function both personally and in their relationships at all ages. Counselling psychology addresses the emotional, social, work, school and physical health concerns people may have at different stages in their lives, focusing on typical life stresses and more severe issues with which people may struggle as individuals and as a part of families, groups and organizations. Counselling psychologists help people with physical, emotional and mental health issues improve their sense of well-being, alleviate feelings of distress and 
resolve crises. They also provide assessment, diagnosis, and treatment of more severe psychological symptoms (www.apa.org).

Across all stages of development (i.e., childhood, adolescence, adulthood, and older age), counselling psychologists focus on: healthy aspects and strengths of clients (whether seen as individuals, couples, families, groups or organizations); environmental/situational influences (how cultural, gender and lifestyle issues shape people's experiences and concerns); issues of diversity and social justice (e.g., advocacy); and the role that career and work play in peoples' lives (www.apa.org).

The increasing rate of psychological problems and their consequences indicate that student centres that provide psychological assistance have to exist. Examining the role of counselling centres for students and the search for the best model started back in the 1930s and 40s (Hodges, 2001). Student counselling centres include the following activities: career counselling, individual and group therapy, prevention programs, consultations, and also training and supervising for future psychologists-counsellors (Sokol, 2009).

The pilot project "The psychological counselling centre for students" (http://www.savetni.org) at the University of Niš is one of the largest and longest running projects of this type among the universities in Serbia. This project is the only university counselling centre in Serbia and it aims to strengthen the individual capacities of young people, improve their social skills, help them adopt problem solving skills, channel anxiety and aggression, and raise the awareness of university and high school students, as well as the entire society about mental health prevention issues. The project has been active since 2007, and the leaders of the project are the Student Association of the University of Niš and the Association of Psychology Students PsihoN. In previous years, the project was supported by the Ministry of Education and Science of the Republic of Serbia and the Rectorate of the University of Niš. The services of the counselling centre are completely free and realized through three departments: Counselling, Education, and the Research Department. In addition to direct counselling, implemented by trained psychotherapists (of the cognitive behavioural, psychoanalytic, and Gestalt orientation), a telephone helpline (which offers counselling services to students over the phone), internet counselling (students get answers via e-mail to questions about their psychological problems/dilemmas), the Counselling Centre offers students numerous seminars, round tables, panel discussions, and similar 
activities on various topics related to youth mental health issues prevention (depression, anxiety, learning disorders, eating disorders, communicational problems, emotional problems, etc.). Moreover, the Counselling Centre organizes continuous empirical assessment of the different aspects of the mental health of students (aggression, susceptibility to stress, self-esteem, life satisfaction, etc.) and their needs, too. In the Counselling Centre, apart from eight therapists, there are 25 volunteers - psychologists and senior-year psychology students. The previous reports on the activities of the Counselling Centre show that students are mostly satisfied with the services provided by the Counselling Centre, that there is a need for these types of psychological services at the university level, and that there is great interest among students to attend seminars and panel discussions on discuss various aspects of mental health (Randjelović et al., 2015.).

University students must adapt to environments plagued by rapid change, ambiguity, uncertainty, and depleted support systems. Students must also cope with a myriad of personal and psychological problems that range from basic adjustment, developmental, academic and learning issues, and career concerns to clinical-level mental illness. Within higher education, there exists a general consensus that the ubiquitous role of personal and psychological counselling is to contribute to student development, adjustment, and learning while preventing dangerous and self-defeating behaviour, thus enabling the individual to thrive in the college community. The mechanisms that colleges and universities utilize to achieve this goal vary dramatically from one institution to another, depending heavily on the institution's philosophy or mission, available resources, and campus needs (https://education.stateuniversity.com).

Students themselves seem to be paying more attention to their mental health. Archer and Cooper (1998) noted that the perceived acceptability of psychological problems has increased, making it more likely an individual will feel that it is socially acceptable to admit a problem exists or to seek counselling. Turner and Quinn (1999) reported a considerable variation in the likelihood that college students would consult with a mental health professional, depending on the specific problem or purpose of the intervention. Students clearly indicated, however, that they value psychological services and expect access to mental health resources while enrolled at a college or university. In a similar vein, Bundy and Ben- 
shoff (2000) found that more than $70 \%$ of surveyed community college students indicated that access to personal counselling would be helpful to them.

The positive effects of counselling services and the importance of university counselling centres for the student population are evident. Early detection and work on the problems that a young person has is not only important for his/her academic achievement, but also for the prevention of potential more serious and larger scale problem. Although the results of the work of psychological counselling centres for students at prestigious European universities have showed the need for the existence for such services to be offered at university, at the universities in the region (Croatia, Bosnia, Montenegro, Bulgaria, Albania, Macedonia), as well as at universities in Serbia, the importance of establishing this type of student service seems not to be recognized (Randjelović et al., 2015).

The need to improve the quality of research data on the severity of the problems of college students has been noted (Bishop et al., 2000). In order to respond in the scientist-practitioner model that many counselling centre professionals profess to follow; future studies must take the time and effort required to improve the research designs that deal with this issue.

\section{METHODOLOGY}

\section{THE PROBLEM AND AIMS OF THE STUDY}

The basic research problem is the attempt to predict the frequency with which problems are manifested in the student population in terms of:

1) learning and intellectual functioning,

2) emotional relationships,

3) communication and social relations based on a set of predictors consisting of:

- satisfaction with relationships and communication in the primary family,

- self-perceived incompetence,

- persistence,

- self-esteem,

- level of loneliness, 
- fear of a negative evaluation from others,

- general satisfaction with life,

- externality of locus of control,

- social self-efficacy,

- emotional competence.

In addition, the research problem also includes the study of the differences in attitudes towards the possibility of offering psychological counselling at university, depending on the level of the aforementioned (predictor) variables of the study.

\section{SAMPLE}

Empirical research was conducted on the sample of 400 students from five different faculties of the University of Niš (the students of the natural sciences and the students of social sciences and humanities were included) during the school year 2018/19. The equal number of students was selected from each faculty $(\mathrm{N}=80$ from each institution): Faculty of Electronic Engineering, Faculty of Medicine, Faculty of Economics, Faculty of Occupational Safety, and Faculty of Philosophy. By gender, the sample consists of $47 \%$ male and $53 \%$ female students and the age of the respondents varied from 19 to 27 .

\section{MEASURING INSTRUMENTS}

A self-concept scale (Bezinović, 1988) designed to measure the self-concepts of adolescents was used. It is a five-point Likert scale, consisting of 77 items constructed in both directions. It also includes seven subscales: Perceived incompetence, Loneliness, Self-respect, Fear of a negative social evaluation, General satisfaction, Locus of control, and Persistence. The reliability of the individual subscales on our sample, expressed by Cronbach's Alpha coefficient, is: $\mathrm{pn}=.849 ; \mathrm{sp}=.687 ; \mathrm{us}=.819$; $\mathrm{snse}=.789 ; \mathrm{oz}=.808 ; \mathrm{lk}=.779$; is $=.890$.

To measure the quality of family communication and satisfaction with the (primary) family, the Faces IV questionnaire was used (Olson \& Gorrall, 2006), that is, the part of the questionnaire which specifically measures the aforementioned aspects. Faces IV provides a comprehensive assessment of family cohesion and flexibility dimensions using six scales. Designed as a self-report assessment for the Circumplex Model of Couple and Family Systems, Faces IV taps both balanced (healthy) and unbalanced (problematic) aspects 
of family functioning. The two balanced Faces IV scales are balanced cohesion and balanced flexibility. These balanced scales are very similar to cohesion and flexibility as measured by Faces II and Faces III.

To estimate emotional intelligence, the Emotional Competence Questionnaire with 45 items was used. This is a shorter version of the Emotional Intelligence Questionnaire UEK-136 (Takšić et al., 2006) constructed according to the theoretical model of Mayer and Salovey (1990), which evaluates three aspects of emotional intelligence: the ability to perceive and understand emotions, the ability to express and label emotions, and the ability to regulate emotions. All of the scales have satisfactory reliability in a variety of samples, from $\alpha=.71$ to $\alpha=.90$.

\section{RESULTS}

In accordance with the set research goals, we first evaluated the extent to which the set of predictors could be used to predict the needs of students to consult with a professional when they have a psychological problem, that is, the extent to which they experience a readiness to consult with a professional for psychological help or counselling.

\begin{tabular}{|l|l|c|c|c|c|c|c|}
\hline Model & \multicolumn{1}{|c|}{ PREDICTORS } & $\mathrm{R}$ & $\mathrm{p}$ & $\mathrm{R}$ & $\mathrm{R}^{2}$ & $\mathrm{R}^{2}$ (adj) & $\mathrm{p}$ \\
\hline \multirow{2}{*}{1} & Satisfaction with family & -.118 & .151 & .153 & .023 & .018 & 0.10 \\
& Family communication & -.042 & .606 & & & & \\
\hline
\end{tabular}

TABLE 1: REGRESSION ANALYSIS IN PREDICTION OF NEED TO CONSULT A PSYCHOLOGIST 


\begin{tabular}{|c|c|c|c|c|c|c|c|}
\hline 2 & $\begin{array}{l}\text { Satisfaction with family } \\
\text { Family communication } \\
\text { Fear of negative evaluation } \\
\text { from others } \\
\text { Externality of locus of control } \\
\text { Persistence } \\
\text { Social self-efficacy } \\
\text { General life satisfaction } \\
\text { Loneliness } \\
\text { Level of self-esteem } \\
\text { Self-perceived incompetence }\end{array}$ & $\begin{array}{r}-.079 \\
-.016 \\
.102 \\
\\
.074 \\
.000 \\
.070 \\
-.038 \\
.110 \\
-.132 \\
-.094\end{array}$ & $\begin{array}{l}.329 \\
.845 \\
.103 \\
\\
.181 \\
.991 \\
.206 \\
.625 \\
.167 \\
.139 \\
.307\end{array}$ & .285 & 081 & .057 & $.000^{* *}$ \\
\hline 3 & $\begin{array}{l}\text { Satisfaction with family } \\
\text { Family communication } \\
\text { Fear of negative evaluation } \\
\text { from others } \\
\text { Externality of locus of control } \\
\text { Persistence } \\
\text { Social self-efficacy } \\
\text { General life satisfaction } \\
\text { Loneliness } \\
\text { Level of self-esteem } \\
\text { Self-perceived incompetence } \\
\text { Comprehension of emotions } \\
\text { Expressing of emotions } \\
\text { Emotional self-control }\end{array}$ & $\begin{array}{r}-.087 \\
-.019 \\
.088 \\
\\
.063 \\
.007 \\
.009 \\
-.043 \\
.101 \\
.181 \\
-.112 \\
.151 \\
.111 \\
-.086\end{array}$ & $\begin{array}{r}279 \\
.820 \\
.155 \\
\\
.246 \\
.923 \\
.875 \\
.581 \\
.198 \\
.049^{*} \\
.218 \\
.034 \\
.122 \\
.267\end{array}$ & .333 & .111 & .080 & $.000^{* *}$ \\
\hline
\end{tabular}

TABLE 1: REGRESSION ANALYSIS IN PREDICTION OF NEED TO CONSULT A PSYCHOLOGIST

Note: $\beta$ - standardized regression coefficient; ${ }^{*} p<.05,{ }^{* *} p<.01$;

$\mathrm{R}$ - multiple correlation coefficient; $\mathrm{R}^{2}$ - coefficient of multiple determination; $\mathrm{R}^{2}$ (adj) - adjusted coefficient of multiple determination

The hierarchical regression analysis proved that all the obtained models are statistically significant, which indicates that based on the set of predictor variables it is possible to explain almost $11 \%$ of the criterion variable-the need of students to consult with a psychologist for a conversation or counselling.

\begin{tabular}{|c|c|r|c|c|c|c|c|}
\hline MODEL & Predictors & \multicolumn{1}{c|}{$\mathrm{R}$} & $\mathrm{p}$ & $\mathrm{R}$ & $\mathrm{R}^{2}$ & $\mathrm{R}^{2}$ (adj) & $\mathrm{p}$ \\
\hline \multirow{2}{*}{1} & Satisfaction with family & .049 & .554 & .094 & .009 & .004 & .184 \\
& Family communication & -.127 & .124 & & & & \\
\hline \hline
\end{tabular}

TABLE 2: REGRESSION ANALYSIS IN PREDICTION OF READINESS TO CONSULT AN EXPERT IN PSYCHOTHERAPY 


\begin{tabular}{|c|c|c|c|c|c|c|c|}
\hline 2 & $\begin{array}{c}\text { Satisfaction with family } \\
\text { Family communication } \\
\text { Fear of negative evaluation } \\
\text { from others } \\
\text { Externality of locus of control } \\
\text { Persistence } \\
\text { Social self-efficacy } \\
\text { General life satisfaction } \\
\text { Loneliness } \\
\text { Level of self-esteem } \\
\text { Self-perceived incompetence }\end{array}$ & $\begin{array}{r}.053 \\
-.121 \\
-.009 \\
\\
.036 \\
-.103 \\
.042 \\
-.069 \\
-.037 \\
.096 \\
.054\end{array}$ & \begin{tabular}{l|}
.528 \\
.162 \\
.887 \\
.533 \\
.142 \\
.462 \\
.396 \\
.652 \\
.298 \\
.574
\end{tabular} & .152 & .023 & -.003 & .545 \\
\hline 3 & $\begin{array}{c}\text { Satisfaction with family } \\
\text { Family communication } \\
\text { Fear of negative evaluation } \\
\text { from others } \\
\text { Externality of locus of control } \\
\text { Persistence } \\
\text { Social self-efficacy } \\
\text { General life satisfaction } \\
\text { Loneliness } \\
\text { Level of self-esteem } \\
\text { Self-perceived incompetence } \\
\text { Comprehension of emotions } \\
\text { Expressing of emotions } \\
\text { Emotional self-control }\end{array}$ & $\begin{array}{r}.046 \\
-.126 \\
-.021 \\
\\
.027 \\
-.099 \\
-.007 \\
-.076 \\
-.044 \\
.051 \\
.040 \\
.088 \\
.097 \\
-.036\end{array}$ & $\begin{array}{l}.581 \\
.144 \\
.748 \\
.637 \\
.165 \\
.911 \\
.354 \\
.592 \\
.592 \\
.676 \\
.235 \\
.196 \\
.651\end{array}$ & .199 & .039 & .006 & .291 \\
\hline
\end{tabular}

TABLE 2: REGRESSION ANALYSIS IN PREDICTION OF READINESS TO CONSULT AN EXPERT IN PSYCHOTHERAPY Note: $\beta$ - standardized regression coefficient; ${ }^{*} p<.05,{ }^{* *} p<.01$;

$\mathrm{R}$ - multiple correlation coefficient; $\mathrm{R}^{2}$ - coefficient of multiple determination; $\mathrm{R}^{2}$ (adj) - adjusted coefficient of multiple determination

Even though the prediction models that deal with the need to seek out psychological counselling proved to be significant, the models which focused on the prediction of the readiness of students to consult with a professional for help and counselling are not statistically significant.

Specifically, a key part of the results which refer to prediction are focused on whether it is possible, and to which extent, to explain the expression of the various modalities of student problems-in particular problems in intellectual functioning and learning, as well as in the spheres of emotional and social life. 


\begin{tabular}{|c|c|c|c|c|c|c|c|}
\hline$\overline{\text { MODEL }}$ & Predictors & $\bar{\beta}$ & $p$ & $\overline{\mathrm{R}}$ & $\overline{\mathrm{R}^{2}}$ & $\mathrm{R}^{2}$ (adj) & $\mathrm{p}$ \\
\hline \multirow{2}{*}{1} & Satisfaction with family & -.060 & .465 & \multirow[t]{2}{*}{.080} & \multirow[t]{2}{*}{.006} & \multirow[t]{2}{*}{.001} & \multirow[t]{2}{*}{.290} \\
\hline & Family communication & .118 & .152 & & & & \\
\hline \multirow{11}{*}{2} & Satisfaction with family & -.062 & .439 & \multirow{11}{*}{.320} & \multirow{11}{*}{.102} & \multirow{11}{*}{.079} & \multirow{11}{*}{$.000^{* *}$} \\
\hline & Family communication & .062 & .453 & & & & \\
\hline & Fear of negative evaluation & .007 & .909 & & & & \\
\hline & from others & & & & & & \\
\hline & Externality of locus of control & .013 & .810 & & & & \\
\hline & Persistence & -.029 & .664 & & & & \\
\hline & Social self-efficacy & .182 & $.001^{* *}$ & & & & \\
\hline & General life satisfaction & .074 & .336 & & & & \\
\hline & Loneliness & .225 & $.004^{* *}$ & & & & \\
\hline & Level of self-esteem & .196 & .026 & & & & \\
\hline & Self-perceived incompetence & -.133 & .145 & & & & \\
\hline \multirow{14}{*}{3} & Satisfaction with family & -.053 & .509 & \multirow{14}{*}{.330} & \multirow{14}{*}{.109} & \multirow{14}{*}{.078} & \multirow{14}{*}{$.000^{* *}$} \\
\hline & Family communication & .070 & .399 & & & & \\
\hline & Fear of negative evaluation & .002 & .976 & & & & \\
\hline & from others & & & & & & \\
\hline & Externality of locus of control & .022 & .684 & & & & \\
\hline & Persistence & -.045 & .512 & & & & \\
\hline & Social self-efficacy & .190 & $.001^{* *}$ & & & & \\
\hline & General life satisfaction & .087 & .260 & & & & \\
\hline & Loneliness & .226 & $.004^{* *}$ & & & & \\
\hline & Level of self-esteem & .189 & $.041^{*}$ & & & & \\
\hline & Self-perceived incompetence & -.135 & .138 & & & & \\
\hline & Comprehension of emotions & .088 & .217 & & & & \\
\hline & Expressing of emotions & -.105 & .144 & & & & \\
\hline & Emotional self-control & .004 & .956 & & & & \\
\hline
\end{tabular}

TABLE 3: REGRESSION ANALYSIS IN PREDICTION OF PROBLEMS IN LEARNING AND INTELLECTUAL FUNCTIONING

Note: $\beta$ - standardized regression coefficient; ${ }^{*} p<.05,{ }^{* *} p<.01$;

$\mathrm{R}$ - multiple correlation coefficient; $\mathrm{R}^{2}$ - coefficient of multiple determination; $\mathrm{R}^{2}$ (adj) - adjusted coefficient of multiple determination

Almost all the models obtained via the hierarchical regression analysis proved to be statistically significant, and so the percentage of the explained variance ranges from $7.9 \%$ for problems in the sphere of emotional relationships all the way to $24,8 \%$ for the sphere of communication and social relations. 


\begin{tabular}{|c|c|c|c|c|c|c|c|}
\hline MODEL & Predictors & $\bar{\beta}$ & $\mathrm{p}$ & $\mathrm{R}$ & $\mathrm{R}^{2}$ & $\mathrm{R}^{2}$ (adj) & $\mathrm{p}$ \\
\hline 1 & $\begin{array}{l}\text { Satisfaction with family } \\
\text { Family communication }\end{array}$ & $\begin{array}{l}.076 \\
.096\end{array}$ & $\begin{array}{l}.351 \\
.238\end{array}$ & .164 & .027 & .022 & $.005^{* *}$ \\
\hline 2 & $\begin{array}{l}\text { Satisfaction with family } \\
\text { Family communication } \\
\text { Fear of negative evaluation } \\
\text { from others } \\
\text { Externality of locus of control } \\
\text { Persistence } \\
\text { Social self-efficacy } \\
\text { General life satisfaction } \\
\text { Loneliness } \\
\text { Level of self-esteem } \\
\text { Self-perceived incompetence }\end{array}$ & $\begin{array}{r}.058 \\
.050 \\
.016 \\
\\
-.024 \\
.013 \\
.032 \\
.087 \\
.054 \\
.122 \\
-.050\end{array}$ & $\begin{array}{l}.476 \\
.552 \\
.794 \\
.667 \\
.845 \\
.569 \\
.266 \\
.499 \\
.173 \\
.587\end{array}$ & .263 & .069 & .045 & $.002^{* *}$ \\
\hline 3 & $\begin{array}{l}\text { Satisfaction with family } \\
\text { Family communication } \\
\text { Fear of negative evaluation } \\
\text { from others } \\
\text { Externality of locus of control } \\
\text { Persistence } \\
\text { Social self-efficacy } \\
\text { General life satisfaction } \\
\text { Loneliness } \\
\text { Level of self-esteem } \\
\text { Self-perceived incompetence } \\
\text { Comprehension of emotions } \\
\text { Expressing of emotions } \\
\text { Emotional self-control }\end{array}$ & $\begin{array}{r}.053 \\
.054 \\
.033 \\
\\
-.025 \\
.033 \\
.062 \\
.092 \\
.063 \\
.176 \\
-.043 \\
-.067 \\
.017 \\
-.078\end{array}$ & $\begin{array}{l}.513 \\
.521 \\
.601 \\
.657 \\
.636 \\
.292 \\
.243 \\
.430 \\
.060 \\
.643 \\
.354 \\
.814 \\
.322\end{array}$ & .281 & .079 & .047 & $.003^{* *}$ \\
\hline
\end{tabular}

TABLE 4: REGRESSION ANALYSIS IN PREDICTION OF PROBLEMS IN EMOTIONAL RELATIONSHIPS

Note: $\beta$ - standardized regression coefficient; ${ }^{*} \mathrm{p}<.05,{ }^{* *} \mathrm{p}<.01$;

$\mathrm{R}$ - multiple correlation coefficient; $\mathrm{R}^{2}$ - coefficient of multiple determination; $\mathrm{R}^{2}$ (adj) - adjusted coefficient of multiple determination

This means that the models function the best when explaining problems related to the communication and social functioning of students, even though the percentage of the explained variance of $10,9 \%$ in the case of learning and intellectual functioning is not negligible. 


\begin{tabular}{|c|c|c|c|c|c|c|c|}
\hline MODEL & Predictors & $\bar{\beta}$ & $\overline{\mathrm{P}}$ & $\overline{\mathrm{R}}$ & $\overline{\mathrm{R}^{2}}$ & $\mathrm{R}^{2}$ (adj) & $p$ \\
\hline 1 & $\begin{array}{l}\text { Satisfaction with family } \\
\text { Family communication }\end{array}$ & $\begin{array}{r}-.107 \\
.294\end{array}$ & \begin{tabular}{r|}
.186 \\
$.000^{* *}$
\end{tabular} & .220 & .048 & .044 & $.000^{* *}$ \\
\hline 2 & $\begin{array}{l}\text { Satisfaction with family } \\
\text { Family communication } \\
\text { Fear of negative evaluation } \\
\text { from others } \\
\text { Externality of locus of control } \\
\text { Persistence } \\
\text { Social self-efficacy } \\
\text { General life satisfaction } \\
\text { Loneliness } \\
\text { Level of self-esteem } \\
\text { Self-perceived incompetence }\end{array}$ & $\begin{array}{r}-.101 \\
.145 \\
.005 \\
.160 \\
-.114 \\
.412 \\
.006 \\
-.059 \\
.030 \\
-.112\end{array}$ & $\begin{array}{r}.168 \\
.057 \\
.935 \\
\\
.001^{* *} \\
.065 \\
.000^{* *} \\
.930 \\
.410 \\
.708 \\
.180\end{array}$ & .492 & .242 & .022 & $.000^{* *}$ \\
\hline 3 & $\begin{array}{l}\text { Satisfaction with family } \\
\text { Family communication } \\
\text { Fear of negative evaluation } \\
\text { from others } \\
\text { Externality of locus of control } \\
\text { Persistence } \\
\text { Social self-efficacy } \\
\text { General life satisfaction } \\
\text { Loneliness } \\
\text { Level of self-esteem } \\
\text { Self-perceived incompetence } \\
\text { Comprehension of emotions } \\
\text { Expressing of emotions } \\
\text { Emotional self-control }\end{array}$ & $\begin{array}{r}.106 \\
.143 \\
.015 \\
\\
.157 \\
-.101 \\
.429 \\
.002 \\
-.055 \\
.060 \\
-.105 \\
-.095 \\
.037 \\
-.011\end{array}$ & $\begin{array}{r}.152 \\
.061 \\
.793 \\
.002^{* *} \\
.110 \\
.000^{* *} \\
.978 \\
.445 \\
.475 \\
.210 \\
.147 \\
.573 \\
.880\end{array}$ & .498 & .248 & .022 & $.000^{* *}$ \\
\hline
\end{tabular}

TABLE 5: REGRESSION ANALYSIS IN PREDICTION OF PROBLEMS IN COMMUNICATION AND SOCIAL RELATIONS

Note: $\beta$ - standardized regression coefficient; ${ }^{*} p<.05,{ }^{* *} p<.01$

$\mathrm{R}$ - multiple correlation coefficient; $\mathrm{R}^{2}$ - coefficient of multiple determination; $\mathrm{R}^{2}$ (adj) - adjusted coefficient of multiple determination

The results pertaining to the differences in the attitudes towards the possibility of psychological counselling at university, depending on the level of the set of research variables (Satisfaction with family, Family communication, Fear of negative evaluation from others, Externality of locus of control, Persistence, Social self-efficacy, General life satisfaction, Loneliness, Level of self-esteem, Self-perceived incompetence, Comprehension of emotions, Ex- 
pressing of emotions, Emotional self-control) confirmed the existence of differences only in certain cases, and so in the remainder of the text only the statistically significant differences will be presented.

\begin{tabular}{|l|c|c|}
\hline \multicolumn{1}{|c|}{$\begin{array}{c}\text { THERE'S A NEED FOR A UNIVERSITY STUDENT } \\
\text { COUNSELLING CENTRE }\end{array}$} & $\begin{array}{c}\text { FEAR OF NEGATIVE } \\
\text { EVALUATION FROM } \\
\text { OTHERS }\end{array}$ & $\begin{array}{c}\text { SATISFACTION WITH } \\
\text { FAMILY }\end{array}$ \\
\hline It is necessary & 34.67 & 58.2857 \\
\hline There is a real need & 33.84 & 55.7941 \\
\hline I am not sure & 30.04 & 57.7083 \\
\hline There's no need for that & 30.63 & 65.0000 \\
\hline Absolutely no need & 27.70 & $.034^{*}$ \\
\hline P & $.001^{* *}$ & 5 \\
\hline \hline
\end{tabular}

TABLE 6: DIFFERENCES IN THE ATTITUDES OF STUDENTS TOWARDS THE POSSIBILITY OF A PSYCHOLOGICAL COUNSELLING CENTRE OPENING, DEPENDING ON THE LEVEL OF EXPRESSED FEAR OF A NEGATIVE EVALUATION FROM OTHERS OF VARIABLES

Note: $* p<.05, * * p<.01$

\begin{tabular}{|c|c|c|c|c|c|c|c|c|}
\hline $\begin{array}{l}\text { Do you } \\
\text { have a } \\
\text { need to } \\
\text { talk and } \\
\text { consult a } \\
\text { psy- } \\
\text { chologist }\end{array}$ & $\begin{array}{l}\text { Family } \\
\text { commu- } \\
\text { nication }\end{array}$ & $\begin{array}{l}\text { Satisfac- } \\
\text { tion with } \\
\text { family }\end{array}$ & $\begin{array}{l}\text { Self-per- } \\
\text { ceived in- } \\
\text { compe- } \\
\text { tence }\end{array}$ & $\begin{array}{l}\text { Persis- } \\
\text { tence }\end{array}$ & $\begin{array}{l}\text { Level of } \\
\text { self-es- } \\
\text { teem }\end{array}$ & $\begin{array}{l}\text { Scale of } \\
\text { loneli- } \\
\text { ness }\end{array}$ & $\begin{array}{l}\text { Fear of } \\
\text { negative } \\
\text { evalua- } \\
\text { tion from } \\
\text { others }\end{array}$ & $\begin{array}{c}\text { General } \\
\text { life satis- } \\
\text { faction }\end{array}$ \\
\hline Never & 38.6033 & 38.5124 & 21.43 & 38.34 & 39.76 & 36.09 & 31.02 & 27.76 \\
\hline Rarely & 38.3590 & 38.6379 & 23.71 & 36.94 & 37.99 & 38.14 & 33.45 & 26.38 \\
\hline $\begin{array}{l}\text { Occasion- } \\
\text { ally }\end{array}$ & 37.7209 & 37.4574 & 23.71 & 37.41 & 37.33 & 40.16 & 34.06 & 26.63 \\
\hline Often & 35.4815 & 34.9259 & 25.15 & 35.88 & 34.52 & 47.11 & 34.81 & 23.07 \\
\hline $\begin{array}{l}\text { Almost } \\
\text { everyday }\end{array}$ & 31.3333 & 30.1667 & 32.67 & 27.00 & 28.00 & 50.00 & 39.00 & 21.00 \\
\hline $\mathrm{P}$ & $.044^{*}$ & $.013^{* *}$ & $.001^{* *}$ & $.004^{* *}$ & $.000^{* *}$ & $.000^{* *}$ & $.007^{* *}$ & $.000^{* *}$ \\
\hline
\end{tabular}

TABLE 7: THE DIFFERENCES IN THE EXPRESSED NEED TO TALK TO A PSYCHOLOGIST DEPENDING ON THE SET Note: ${ }^{*} \mathrm{p}<.05, * * \mathrm{p}<.01$ 
The results of the analysis of variance indicated that there are differences in the attitudes of the students towards possible psychological consultations via an SOS phone line, in that those individuals who scored highest on the scale of understanding emotions are almost certainly ready to seek help via an SOS phone line, while with the decrease in the ability to understand emotions, there is a decrease in the possibility of students seeking out this kind of help and counselling (Table 7).

\begin{tabular}{|l|r|}
\hline $\begin{array}{l}\text { Would you ask for help via the SOS telephone within psy- } \\
\text { chological counselling for students }\end{array}$ & Comprehension of emotions \\
\hline Absolutely yes & 67.3333 \\
\hline Probably yes & 57.1081 \\
\hline Not sure & 57.4667 \\
\hline Probably not & 56.5672 \\
\hline Definitely not & 56.6846 \\
\hline p & $.024^{*}$ \\
\hline \hline
\end{tabular}

TABLE 8: DIFFERENCES IN THE EXPRESSED READINESS TO SEEK HELP AND COUNSELLING VIA AN SOS PHONE LINE DEPENDING ON THE ABILITY TO COMPREHEND EMOTIONS

Note: ${ }^{*} \mathrm{p}<.05,{ }^{* *} \mathrm{p}<.01$

In the remaining text, the differences in the frequency of occurrence of problems in the spheres of learning - intellectual functioning, and the emotional and social functioning of students are studied, depending on the level at which certain significant variables are expressed among them.

\begin{tabular}{|l|r|r|r|r|}
\hline $\begin{array}{l}\text { Learning problems and } \\
\text { intellectual function- } \\
\text { ing }\end{array}$ & $\begin{array}{r}\text { Social self-effica- } \\
\text { cy_ }\end{array}$ & $\begin{array}{r}\text { Family com- } \\
\text { munication }\end{array}$ & $\begin{array}{c}\text { Level of self-es- } \\
\text { teem }\end{array}$ & $\begin{array}{l}\text { Scale of lone- } \\
\text { liness }\end{array}$ \\
\hline Very often & 83.6429 & 39.2143 & 32.00 & 41.43 \\
\hline Sometimes & 78.1958 & 37.5455 & 36.57 & 39.55 \\
\hline Not sure & 79.8182 & 33.5455 & 35.36 & 45.55 \\
\hline Very rarely & 83.4366 & 38.3944 & 39.27 & 38.35 \\
\hline Never & 87.8831 & 38.7051 & 39.65 & 36.85 \\
\hline$p$ & $\mathbf{. 0 0 0 * *}$ & $.032^{*}$ & $\mathbf{. 0 0 0}^{* *}$ & $\mathbf{. 0 4 2}$ \\
\hline
\end{tabular}




\begin{tabular}{|l|r|r|r|r|}
\hline $\begin{array}{c}\text { Learning problems and } \\
\text { intellectual function- } \\
\text { ing }\end{array}$ & $\begin{array}{r}\text { Scale of Persis- } \\
\text { tence }\end{array}$ & $\begin{array}{c}\text { Comprehen- } \\
\text { sion of emo- } \\
\text { tions }\end{array}$ & $\begin{array}{r}\text { Expressing of } \\
\text { emotions }\end{array}$ & $\begin{array}{r}\text { Emotional } \\
\text { self-control }\end{array}$ \\
\hline Very often & 32.86 & 52.0000 & 50.0714 & 59.0714 \\
\hline Sometimes & 36.84 & 55.9231 & 50.9441 & 59.7832 \\
\hline Not sure & 34.45 & 55.6364 & 50.0909 & 60.4091 \\
\hline Very rarely & 37.79 & 58.6690 & 53.0775 & 62.8310 \\
\hline Never & 38.77 & 57.6667 & 52.1667 & 62.5641 \\
\hline p & $\mathbf{. 0 1 3 * *}$ & $\mathbf{. 0 0 0 * *}$ & $.028^{*}$ & $\mathbf{. 0 2 1}$ \\
\hline \hline
\end{tabular}

TABLE 9: A AND B - DIFFERENCES IN THE EXPRESSION OF THE PROBLEM OF LEARNING AND INTELLECTUAL FUNCTIONING DEPENDING ON CERTAIN SIGNIFICANT VARIABLES

$$
\text { Note: }{ }^{*} \mathrm{p}<.05,{ }^{* *} \mathrm{p}<.01
$$

The findings presented in tables $9 \mathrm{a}$ and $9 \mathrm{~b}$ show that there are differences in the frequency of occurrence of the problem of learning and intellectual functioning among students. Therefore, students with the most pronounced abilities of social self-efficacy least of all, that is, almost never have these problems, while students who have the lowest self-esteem are also most susceptible to the emergence of problems in intellectual functioning. Also, with the increase in the ability to understand, express, and manage emotions, there is a decrease in the chance that problems regarding learning and the intellectual activities will occur.

\begin{tabular}{|l|r|r|r|r|r|r|}
\hline $\begin{array}{l}\text { Emotional } \\
\text { relation- } \\
\text { ships }\end{array}$ & $\begin{array}{r}\text { Family com- } \\
\text { munication }\end{array}$ & $\begin{array}{c}\text { Self-per- } \\
\text { ceived in- } \\
\text { competence }\end{array}$ & $\begin{array}{c}\text { Persis- } \\
\text { tence }\end{array}$ & $\begin{array}{c}\text { Level of } \\
\text { self-esteem }\end{array}$ & $\begin{array}{c}\text { Loneli- } \\
\text { ness }\end{array}$ & $\begin{array}{c}\text { Generallife } \\
\text { satisfac- } \\
\text { tion }\end{array}$ \\
\hline Very often & 35.9250 & 26.80 & 35.18 & 34.57 & 45.08 & 23.75 \\
\hline Sometimes & 37.2867 & 23.74 & 36.60 & 36.97 & 39.30 & 26.14 \\
\hline Not sure & 35.7407 & 26.41 & 35.52 & 35.30 & 44.30 & 25.00 \\
\hline Very rarely & 39.1550 & 22.02 & 38.32 & 39.80 & 36.61 & 27.60 \\
\hline Never & 39.1148 & 20.98 & 38.95 & 39.56 & 36.74 & 27.97 \\
\hline p & $\mathbf{. 0 0 4}$ & $\mathbf{. 0 0 0 * *}$ & $\mathbf{. 0 1 9}^{* *}$ & $\mathbf{. 0 0 0}^{* *}$ & $\mathbf{. 0 0 0}^{* *}$ & $.000^{* *}$ \\
\hline \hline
\end{tabular}

TABLE 10: DIFFERENCES IN THE EXPRESSION OF PROBLEMS IN EMOTIONAL RELATIONSHIPS DEPENDING ON THE SET OF VARIABLES

$$
\text { Note: }{ }^{*} \mathrm{p}<.05,{ }^{* *} \mathrm{p}<.01
$$


Those students who had the highest quality of family communication in their primary family were least of all affected by emotional problems. In the same way, the emergence of emotional problems is tied to the variable of self-esteem, or the variable of persistence, so that students with more pronounced self-esteem and persistence rarely have problems pertaining to emotional functioning.

\begin{tabular}{|c|r|r|r|r|r|r|}
\hline $\begin{array}{c}\text { Communica- } \\
\text { tion and social } \\
\text { relations }\end{array}$ & $\begin{array}{c}\text { Family com- } \\
\text { munication }\end{array}$ & $\begin{array}{c}\text { Self-per- } \\
\text { ceived in- } \\
\text { competence }\end{array}$ & $\begin{array}{c}\text { Persis- } \\
\text { tence }\end{array}$ & $\begin{array}{c}\text { Level of } \\
\text { self-es- } \\
\text { teem }\end{array}$ & $\begin{array}{c}\text { Loneli- } \\
\text { ness }\end{array}$ & $\begin{array}{c}\text { Social } \\
\text { self-effi- } \\
\text { cacy }\end{array}$ \\
\hline VERY OFTEN & 32.5625 & 30.31 & 30.73 & 30.13 & 51.93 & 62.1875 \\
\hline SOMETIMES & 36.3750 & 23.97 & 36.51 & 36.68 & 40.85 & 73.8750 \\
\hline NOT SURE & 35.5357 & 24.11 & 37.50 & 38.04 & 42.46 & 79.2500 \\
\hline VERY RARELY & 38.4770 & 23.18 & 37.50 & 38.17 & 38.24 & 83.5665 \\
\hline NEVER & 39.4636 & 21.68 & 38.35 & 39.38 & 36.17 & 89.3273 \\
\hline P & $\mathbf{. 0 0 0 * *}$ & $\mathbf{. 0 0 4}^{* *}$ & $\mathbf{. 0 0 4}^{* *}$ & $\mathbf{. 0 0 0}^{* *}$ & $\mathbf{. 0 0 0}^{* *}$ & $\mathbf{. 0 0 0}$ \\
\hline
\end{tabular}

\begin{tabular}{|l|r|r|r|r|r|}
\hline $\begin{array}{c}\text { COMMUNICATI } \\
\text { ON AND } \\
\text { SOCIAL } \\
\text { RELATIONS }\end{array}$ & $\begin{array}{c}\text { Fear of neg- } \\
\text { ative evalu- } \\
\text { ation from } \\
\text { others }\end{array}$ & $\begin{array}{c}\text { General life } \\
\text { satisfaction }\end{array}$ & $\begin{array}{c}\text { Externality of } \\
\text { locus of con- } \\
\text { trol }\end{array}$ & $\begin{array}{c}\text { Expressing of } \\
\text { emotions }\end{array}$ & $\begin{array}{c}\text { Emotional } \\
\text { self-control }\end{array}$ \\
\hline VERY OFTEN & 40.19 & 21.31 & 28.13 & 43.0625 & 53.8125 \\
\hline SOMETIMES & 34.88 & 25.82 & 27.04 & 50.1111 & 60.2639 \\
\hline NOT SURE & 32.39 & 26.18 & 29.11 & 49.8571 & 61.0714 \\
\hline VERY RARELY & 32.62 & 26.73 & 28.67 & 52.9080 & 62.1609 \\
\hline NEVER & 31.82 & 27.67 & 29.60 & 53.2273 & 62.2636 \\
\hline P & $\mathbf{. 0 0 1 * *}$ & $\mathbf{. 0 0 0 * *}$ & $\mathbf{. 0 0 0 * *}$ & $\mathbf{. 0 0 0 * *}$ & $\mathbf{. 0 0 3 * *}$ \\
\hline \hline
\end{tabular}

TABLE 11: A AND B. DIFFERENCES IN THE EXPRESSION OF PROBLEMS IN COMMUNICATION AND SOCIAL RELATIONS DEPENDING ON THE SET OF VARIABLES

Note: ${ }^{*} \mathrm{p}<.05,{ }^{* *} \mathrm{p}<.01$

It was proven that numerous variables can be of great importance for the emergence of problems in social functioning and communication among students. Thus, with the increase in the ability to express and manage emotions, the possibility for the emergence of the aforementioned problems among students decreases. On the 
other hand, students with a more pronounced fear of a negative evaluation from others, and also those students who feel socially isolated, have problems communicating with others and problems in the social sphere more often.

\section{DISCUSSION AND CONCLUSION}

The effects of the global financial and economic crisis spread quickly and had a great impact on the economies of all countries and all the sectors of a country, including an important impact on tertiary education systems all over the world. However, the impact of the financial and economic crisis on tertiary education systems varied among countries, due to the different forms and structures of tertiary education systems in individual countries (Eggins \& West 2010; Skrbinjek \& Lesjak 2014). The increasing rate of psychological problems and their consequences indicate that student centres that provide psychological assistance have to exist.

Our findings indicated that there are differences in the readiness of members of the student population to ask for psychological help and counselling, depending on their different individual characteristics such as quality of communication and satisfaction with one's primary family, the extent of self-perceived incompetence, fear of a negative evaluation from others, self-esteem, persistence, and even general satisfaction with life. In addition, it is clear that a significant number of variables can be of importance for the emergence of problems both in the learning process, and in emotional relationships, social relations, as well as in communication in general. In that case, variables characterized as important are those which stem from the context of the primary family (satisfaction with one's family and the quality of communication in one's primary family); but what is also important are the level of self-esteem, persistence, and general satisfaction with life. Students with a much more pronounced self-perception of incompetence, fear of a negative evaluation from others, a feeling of loneliness, and a low social self-efficacy are more susceptible to the emergence or manifestation of problems in the intellectual, affective, and sphere of social relations. On the other hand, students who efficiently express, understand, and more easily manage their emotions are less prone to the emergence of problems in any of these three aforementioned spheres. 
These results are also clearly supported by the data obtained by establishing a prediction model for the frequency of occurrence of the problems in the spheres of intellectual, affective, and social activities of the student population. The percentage of the explained variance ranges from $7,9 \%$ in the case of affective relations, to $10.9 \%$ in the case of intellectual functioning and problems in the sphere of learning. The prediction models for problems in communication and the social relations of students proved to be the best, where the percentage of variance is as high as $24.8 \%$. In all the prediction models the set of predictors consisted of Satisfaction with family, Family communication, Fear of negative evaluation from others, Externality of locus of control, Persistence, Social self-efficacy, General life satisfaction, Loneliness, Level of self-esteem, Self-perceived incompetence, Comprehension of emotions, Expressing of emotions, Emotional self-control.

The quality of education and the state of the system meant to build and create highly educated individuals and primarily potential experts have an undeniable impact on the standard and quality of life of students. On the other hand, healthy, successful, and satisfied students are a guarantee for the emergence and sustainability of the intellectual elite of a society. In that sense, the study of potential and significant factors which could have either a positive or a negative impact on the mental health of the student population is, and should be, an imperative in the scientific and professional community.

Archer, J., Jr. and Cooper, S. (1998). Counselling and mental health services on campus: A handbook of contemporary practices and challenges. San Francisco: Jossey-Bass.

Bezinović, P. (1988). Prikaz skala za mjerenje nekih aspekata samopoimanja. U: N. Anić (Ed.) Praktikum iz kognitivne i bihevioralne terapije, Zagreb: Društvo Psihologa Hrvatske.

Bishop, J. B. (2006). College and University Counselling Centres: Questions in Search of Answers, Journal of College Counselling, 9(1), 6-19.

Bishop, J. B., Gallagher, R. P., and Cohen, D. (2000). College students' problems: Status, trends, and research. In D. C. Davis \& K. M. Humphrey (Eds.), College counselling: Issues and strategies for a new millennium. Alexandria, VA: American Counselling Association.

Bundy, A. P. and Benshoff, J. M. (2000). Students' perceptions of need for personal counselling services in community colleges. Journal of College Counselling, 3, 92-99. 
Eggins, H. and West, P. (2010). The global impact of the financial crisis: main trends in developed and developing countries. Higher Education Management and Policy, 22(3), 1-16.

Olson, D. H. and Gorall, D. M. (2006). FACES IV and the Circumplex Model. Minneapolis, MN: Life Innovations.

Randjelović, D., Mitrović, M., and Todorović, D. (2015). Psychological counselling centre for students - need, desire, necessity, Collection of Papers of the Faculty of Philosophy, XLV (3), 143-166.

Skrbinjek, V., \& Lesjak, D. (2014). Changes in higher education public funding during economic and financial crisis. In Human capital without borders: knowledge and learning for quality of life: proceedings of the Management, Knowledge and Learning International Conference (pp. 1377-1386).

Takšić, V., Moharić, T., and Munjas, R. (2006). Emocionalna inteligencija - teorija, operacionalizacija, primjena i povezanost s pozitivnom psihologijom. Rijeka, Croatia: Filozofski fakultet

Turner, A. L. and Quinn, K. F. (1999). College students' perceptions of the value of psychological services: A comparison with APA's public education research. Professional Psychology: Research and Practice, 30, 368-371.

https://education.stateuniversity.com/pages/2317/Personal-Psychological-Counselling-At-Colleges-Universities.html (visited on: 14. 11. 2021.)

https://www.apa.org/ed/graduate/specialize/counselling (visited on: 14.11.2021.)

http://www.savetni.org (visited on: 14.11.2021.)

https://education.stateuniversity.com (visited on: 14.11.2021.) 
ДУШАН Љ. ТОДОРОВИЋ

УНИВЕРЗИТЕТ У НИШУ

ФИЛОЗОФСКИ ФАКУЛТЕТ

ДЕПАРТМАН ЗА ПСИХОЛОГИЈУ

ДУШАН Ј. РАНЪЕЛОВИЋ

УНИВЕРЗИТЕТ У ПРИШТИНИ СА ПРИВРЕМЕНИМ СЕДИШТЕМ

У КОСОВСКОЈ МИТРОВИЦИ, ФИЛОЗОФСКИ ФАКУЛТЕТ

КАТЕДРА ЗА ПСИХОЛОГИЈУ

ДАРИНКА Д. ИЛИЋ

СТУДЕНТСКИ КУЛТУРНИ ЦЕНТАР НИШ

ПСИХОЛОШКО САВЕТОВАЛИШТЕ ЗА СТУДЕНТЕ

РЕЗИМЕ

УНИВЕРЗИТЕТСКИ ЦЕНТАР ЗА ПСИХОЛОШКО

САВЕТОВАЮЕ - ЕМПИРИЈСКА СТУДИЈА И ПОТЕНЦИЈАЛНИ

ЗНАЧАЈ ЗА УНАПРЕЂЕЊЕ КВАЛИТЕТА ЖИВОТА СТУДЕНАТА

Психологија саветовања ठави се емоционалним, друштвеним, пословним, школским и физичким здравственим проблемима које људи могу имати у различитим фазама свог живота, фокусирајући се на типичне животне стресове и озбиљније проблеме са којима се људи могу борити као појединци и као део породице, групе и организације. Растућа стопа психолошких проблема и њихових последица указује на то да морају постојати студентски центри који пружају психолошку помоћ. Пилот пројекат „Психолошко саветовалиште за студенте“ Универзитета у Нишу један је од највећих и најдуговечнијих пројеката овог типа међу универзитетима у Србији. Основни проблем истраживања представља покушај предикције учесталости испољавања проблема студената у учењу и интелектуалном функционисању, емоционалним односима, комуникацији и социјалним односима на основу селф-концепта, квалитета породичне комуникације и задовољства примарном породицом. Узорак је чинило 400 студената Универзитета у Нишу. Коришћена је Скала за испитивање селф-концепта (Bezinović, 1988) за мерење селф-концепта адолесцената, за мерење квалитета породичне комуникације и задовољства породицом (примарном) коришћен је Faces IV упитник (Olson \& Gorrall, 2006). 3a процену емоционалне интелигенције коришћен је Упитник емоционалне компетенције (Takšić, Moharić, Munjas, 2006) који процењује три аспекта емоционалне интелигенције: способност уочавања и разумевања емоција, способност изражавања 
и именовања емоција и способност управљања и регулисања емоцијама. Резултати нашег истраживања указују на то да постоје разлике у спремности припадника студентске популације да затраже психолошку помоћ и саветовање, у зависности од њихових различитих индивидуалних карактеристика као што су квалитет комуникације и задовољство примарном породицом, степен самоопажене некомпетентности, страх од негативне оцене других, самопоштовање, упорност, па чак и опште задовољство животом. Поред тога, јасно је да значајан број варијабли може бити од значаја за настанак проблема како у процесу учења тако и у емоционалним односима, друштвеним односима, као и у комуникацији уопште. Готово су се сви модели добијени кроз процедуру хијерархијске регресионе анализе показали статистички значајним, тако да проценат објашњене варијансе иде од 7,9\%, када је у питању проблематика у сфери емоционалних односа, па до $24,8 \%$, када је у питању сфера комуникације и социјалних односа. То значи да модели најбоље функционишу управо у објашњењу проблематике комуникација и друштвеног функционисања студената, иако проценат објашњене варијансе од 10,9\% у случају проблема учења и интелектуалног функционисања никако није занемарљив. Испитивање потенцијалних и значајних фактора који могу деловати ठило позитивно било негативно на ментално здравље студентске популације јесте и треба бити императив научне и стручне јавности.

КљУчнЕ РЕчи: психолошко саветовалиште за студенте; предвиђање проблема у студентској популацији; ментално здравље студената.

Овај чланак је објављен и дистрибуира се под лиценцом Creative Commons Ауторство-Некомерцијално Међународна 4.0 (СC BY-NC 4.0 |

https://creativecommons.org/licenses/by-nc/4.0/).

This paper is published and distributed under the terms and conditions of the Creative Commons Attribution-NonCommercial International 4.0 licence (CC BY-NC 4.0 | https://creativecommons.org/licenses/by-nc/4.0/). 